\title{
A discussion framework of store image and patronage: A literature review
}

\begin{abstract}
:
Purpose - This paper aims to critically review the literature that explores the relationships between store image and store patronage behaviour, thereby providing the practical analytical framework with measurements that aids marketers to build strategical marketing plans to attract loyal customers to their retail shops.
\end{abstract}

Design/methodology/approach -A systematic literature review method was applied to this study which analysed the literature of peer-reviewed articles in English-language journals and specific online databases. In total, 863 peer-reviewed articles which were published between 1950 and 2017 were examined to provide the practical framework with measurements for further discussion.

Findings - It was found that within the eight identified dimensions of store image, namely, merchandise, service, convenience, promotion, clientele, physical facilities, atmosphere and institutions, there are corresponding sub-sections that need to be recognised, e.g. merchandise involves quality, assortment, price, fashionability and 
guarantee. Therefore, in this paper, these dimensions have been analysed and discussed in the context of their impact on store patronage. However, due to the lack of clarity with respect to the predictors of store patronage, there has been confusion in academic discussions. Therefore, it has been proposed that store patronage should be investigated using the following two parameters: store image alignment of customers and managers and past purchase experiences of customers.

Research limitations/implications - This study contributes to providing a useful discussion platform with an analytical framework and measurements. Due to the selected term-based search method, even with the authors' maximum effort, the number of selected publications is limited.

Practical implications - This study introduces a practical conceptual framework for the measurements that need to be utilised by the marketers while building marketing strategies for attracting consumers to enhance their patronage behaviours. Retail services need to create a reinvented discussion platform with respect to store image and patronage. Consumers may perceive store image as being embedded in the store environment as a trigger for their patronage behaviour and, using the proposed 
analytical framework, the retailers can analyse and refine their marketing plans effectively.

Originality/value - This study presents the overall reappraisals of the initial literature with regard to the holistic development, implications and impact of store image on store patronage. Moreover, the paper seeks to provide a robust discussion paradigm for developing perspectives for improving patronage behaviours, thereby bridging the gap between store image and store patronage by attempting to use the relevant literature to contribute to constructive future discussions and useful dimensions while building marketing strategies.

Keywords: store image, store patronage, dimensions, behaviour, review

Paper type: Literature Review 


\section{Introduction}

\section{Background of this study}

Store patronage encapsulates the degree to which a consumer returns to a store and makes repeated purchases. If a store can maintain high store patronage, it will be able to generate a large share of the consumer spending (Hu and Jasper, 2006; Pan and Zinkhan, 2006; Theodoridis and Chatzipanagiotou, 2009). Store image is defined as the manner in which a consumer views a business. Therefore, a business can attract new customers by creating a store image that is in line with or surpasses the expectations of the consumer (Hu and Jasper, 2006; Pan and Zinkhan, 2006). It is by combining store patronage with store image that a business can create a growing and loyal consumer base.

Store patronage and store image are constructs that are created in the mind of the consumers. Therefore, the perception that the consumers develop while evaluating the variety of factors that contribute to the attractiveness of a store will affect the overall store patronage or store image for the consumers. This theme has attracted researchers to present useful tools that can be utilised by both marketers and retailers to enhance their consumers' store patronage (Arnold et al., 1983; Delener, 2011; Erdem and Oumlil, 1999; Jolson and Spath, 1973; Kelly and Smith, 1983; Maruyama and Wu, 2014; Ogle 
et al., 2004; Stephenson, 1969; Yavas and Babakus, 2009). Although academic discussions by prominent researchers so far, as cited above, have framed the practical analytical platform with measurements that can be applied to the practitioners, it has not been presented to the marketers yet. Therefore, this study expects to provide some useful tools that could enable businesses to develop target markets.

\section{Aim and Objectives}

This study critically reviews the literature that explores the relationships between store image and store patronage behaviour to investigate the influence of the consumers' perceived store image components on the consumer patronage behaviour of shopping stores. By doing so, this paper aims to present a practical and analytical framework with measurements that the marketers and retailers can utilise to frame marketing plans to influence the patronage behaviour of consumers.

This paper has three objectives to achieve this aim:

- To conduct an extensive and critical literature review in the fields of store image and patronage studies using relevant academic journals in the last fifty years.

- To present a practical framework to continue the further discussion for contributing towards building marketing strategies for retailers. 
- To provide useful tools for retailers who aim to enhance the store patronage of their customers.

\section{Methodology}

\section{Overall methodology}

A term-based search method was applied to this study which analysed the literature of peer-reviewed articles in English-language journals and specific online databases (Groß, 2014). Based on this desk research approach, a systematic literature review of the articles in the fields of store image and patronage studies were conducted to explore what extent existing research has progressed in identifying relationships between store image and patronage to provide a practical framework for further discussion (Baumeister 2013; Cooper, 2003; Webster and Watson, 2002).

\section{Data sources and study selections}

The published studies were identified through searches in EBSCO and ScienceDirect databases during the period from 1950 to 2017. Keywords, titles and abstract information were checked and selected (Levy and Ellis, 2006). The main search terms were 'store image' and 'store patronage.' The symbol \# was used for identifying 
all possible words with these two key terms. For instance, patron\# was used to search, e.g. patronage, patrons, patronize and patronise. In addition, the lists of references from reviewed papers and book chapters that were included in this study and other relevant articles were systematically reviewed.

Only English articles were considered. Unpublished studies, abstracts, dissertations, book chapters and studies that have been published in nonpeer-reviewed journals were not considered to make our review precise. A manual review of the title information of all identified references revealed that 863 articles had to be further reviewed for potential inclusion in the present review.

\section{Theoretical discussion}

\section{Store image and dimensions}

First, it is imperative to understand how store image is created to understand the complex decision-making that takes place in the mind of the consumer. Thus, research on store image has been conducted.

The concept of store image is quite problematic to understand, as it has no clear universally accepted definitions. However, a number of explanations that have been provided by renowned scholars about store image offer a clear overview of the subject area. Boulding (1956) demonstrated how the human mind often oversimplifies complex 
situations, as is regularly seen via the creation of stereotypes of diverse cultures. He concluded that, accordingly, store image is associated with the oversimplification of a complex situation. Arons (1960), on the other hand, linked the complex nature of a store image with the complex relationship between a retailer and a consumer that needs to be initiated for a store image to be characterised in the mind of the consumer. Martineau (1958) offered a clarification of the explanations provided by Boulding and Arons by concluding that store image is the way in which a store is perceived in the mind of the shoppers.

Today, we consider store image to be an important variable in the functioning of human behaviour (Bagdare, 2015; Belwal and Belwal, 2017; Diallo and Cliquet, 2016; Jha and Arora 2012; Lindquist, 2001). 'This was established by the study by Boulding (1950) that found a correlation between economic activities and the effects of outward images. Early theories concluded that 'gravity' - the distance between a consumer and a store - is the determining factor of store loyalty (Thompson, 1967). However, Martineau (1958) suggested that a greater number of factors affect store loyalty by drawing focus to the following question: What draws shoppers to one store instead of another?

A variety of studies have attempted to answer this question, which has resulted in the selection of definitions of store image. Consequently, no conclusive definition has 
become apparent. However, the theme of the simplest consumer perception of a complex organisation is apparent in the variety of researches that have been conducted over the last few decades (Aron, 1960; Barr and Field, 1997; Doyle, 2001; Doyle and Fenwick, 1974; Engel and Blackwell, 1982; Gil-Saura, 2016; Houston and Nevin, 1981; James et al., 1976; Steenkamp and Wedel, 1991).

Given the in-depth quality of Lindquist's (1974) analysis of twenty-six studies related to store image, his definition of store image shall be used throughout this paper with additional insights into supplement knowledge as follows:

'Store image is complex by nature and consists of a combination of tangible or functional factors and intangible or psychological factors that a consumer perceives to be present' (1974, p. 31)

Martineau (1958) has also confirmed Lindquist’s deduction, having been able to identify similar overriding factors that affect a store's image. These factors are the functional qualities and the psychological factors. These two dimensions contribute to a store's outward image as follows:

1. Functional qualities refer to those tangible and intangible elements that make up a store and can easily be compared with that of a competitor. Table 1 provides a 
detailed list of those elements. In the minds of the consumers, these elements are primarily seen to rated on a 'good-bad' scale.

2. Psychological factors are closely related to the attributes of a store, and they appeal to a consumer's personality, thereby encouraging the creation of a sense of belonging in his or her mind through the development of feelings, e.g. friendliness (Lindquist, 1974).

This implies that a store's image is crafted from a combination of the two overriding factors that can be broken down into contributing factors, as seen in Table 2 .

Table 1 identifies the works of twenty-four scholars who have investigated attributing factors that affect a store's image. As their works were unable to identify more than eight contributing factors that affect a store's image, namely, merchandise, service, convenience, promotion, clientele, physical facilities, atmosphere and institutions, this view shall be adopted throughout this paper.

\section{Insert 'Table 1: Factors that affect store image' here}

After conducting further investigation into the studies that have been recognised in Table 1, the authors found that within the eight identified dimensions that have been shown in Table 2, there are corresponding sub-sections that must be recognised. For 
example, Rich (1963) suggested that merchandise includes the following sub-sections: quality, assortment and price. Comparably, Bucklin (1963) suggested that merchandise has the following sub-sections: fashion, guarantee and price. Tables 1 and 2 have been created to encapsulate all the suggested sub-sections, as described by the scholars.

\section{Insert 'Table 2: Sub-sections of the factors that affect store image' here}

Table 2 shows the thirty-two sub-sections (quality, selection, etc.) that determine the eight dimensions (merchandise, promotion, etc.). Consequently, the eight dimensions are used to determine the two 'characterising images' (functional qualities and psychological attributes), which, in turn, used to define a store's image in the minds of the consumers (Lindquist, 1974; Martineau, 1958).

Emphasis shall initially be placed on the explanation of the parameters that affect the eight dimensions to understand the relevance of the findings of the individual scholars and definitions will be guided from the work of past scholars, which shall form a basis for the hypotheses. 


\section{Store patronage}

As humans, we are neither purely rational nor consistent; we are heavily influenced by external influences (Böhler, 2015). It is for this reason that the store patronage of consumers is not purely influenced by logical reasoning, and it is critical that the retail managers understand this, as it would enable them to identify and target those consumers who are most likely to purchase a product from their stores (Bhat and Singh, 2017; Clement et al., 2015; Pan and Zinkhan, 2006).

Due to the visible applications of store patronage, a number of studies have been conducted on the subject area with the most notable recent study being that by Baker et al. (2002) who have confirmed the long-standing credo that store patronage comprises a variety of independent variables, such as service, parking facilities and fast checkout (Thelen and Woodside, 1997). However, the paper by Baker et al. (2002) reveals that the consumers process these independent variables in the following three stages: (a) evaluating them one at a time, (b) bundling them into generic constructs (e.g. store atmosphere), (c) generating a reaction amongst consumers, no matter whether that is positive or negative (e.g. no purchase, one-off purchase or return visit). This simple three-stage realisation encompasses the overriding theme that is present in the crafting of store patronage in the eyes of the consumers (Baker et al., 2002). 
Store patronage is a complicated subject due to the number of conflicting ideas that are presented with it, such as the accepted idea that offering low-priced products will increase the turnover and, in turn, would result in high store patronage (Tigert, 1983; Walters and Rinne, 1986) (Table 3).

\section{Insert 'Table 3: Factors that influence store patronage’ here}

However, scholars are also in agreement that the shoppers who have limited product information will perceive a product's price as a factor that determines its quality - with a lower price resulting in the assumption of lower quality, thereby leading to low store patronage (Rao and Monroe, 1988). This lack of clarity with respect to the predictors of store patronage is due to the diverse desires of the consumers who visit a store (Pan and Zinkhan, 2006).

Osman (1993) proposed a conceptual model that suggested that if retailers meet or exceed the expectations of a customer, the customer will have a positive experience, which can potentially lead to repeated purchases being made and increased loyalty. Similarly, a low degree of alignment between the perceived image of the customer and 
the retailer of a store could potentially lead to a customer's declining loyalty towards that store.

Osman (1993) proposed some analytical frameworks for the future using which Burt and Carralero-Encinas (2000) discussed some issues that are related to the management of the store image and the gap that could exist between the views of managers and customers with respect to store image. For example, Birtwistle et al. (1999) argued that store image is the perception that is held by the front-line staff of a store and its customers. According to their empirical study, frontline staff must have high esteem for the store, its goods and services and the shop environment in which they work when they communicate with the customers.

More specifically, Birtwistle et al. (1999) argued, based on their empirical study, that some companies perceived their employees to be corporate assets. In those instances, the customer feedback indicated that the shops and their front-line staff were not necessarily friendly or helpful. Moreover, the quality of service in such companies’ stores did not live up to the expectations of the customers. This gap implies that to remedy this situation store managers should aim to consider the perceptions of their front-line staff regarding the store image to be more critical than the expectations of their customers. 
Therefore, it is suggested that store patronage is linked to the following two parameters:

1. Customer and manager store image alignment - the managers perceived the areas of importance as being aligned with those of the consumers, e.g. parking facilities, cleanliness and merchandising (Osman, 1993).

2. Past purchase experiences - the memories of the consumer from previous visits to the store, e.g. quality, variety and after-purchase services (Osman, 1993).

Insert 'Table 4: Independent variables that contribute to the consumers' patronage' here

Table 4 illustrates the range and the scope of the independent factors that affect a consumer's store patronage. This can, perhaps, provide the reason behind why consumers choose products from a variety of stores. Once a store can meet the functional and psychological demands of a consumer, that consumer will return for either making similar or different purchases (Belwal and Belwal, 2017; Goodman and Remaud, 2015; Osman, 1993). This consumer will then begin to have a sense of patronage with respect to 
the specific store, provided that their demands from the store are met consistently (Osman, 1993). Scholars have debated about the various independent variables that have had a profound impact on consumers and have discovered that little synergy can be found between the factors (Hsu et al., 2010; Nilsson et al., 2015).

On this point, Belwal and Belwal (2017) highlighted the importance of having a holistic view while analysing consumers' perceptions and behaviours in the globalised era. In the current multi-religious and cultural context, they discussed some essential dimensions on which a consensus or agreement with respect to consumers' store image and patronage studies have not yet been reached. They analysed that the consumers' focus has been shifting to the modern formats of the retail shops, and they also revealed the fact that local and socio-cultural reasons attract consumers. Especially, they emphasised that researchers should take into consideration 'the different context of local conditions and religions’ (Belwal and Belwal, 2017, p. 587). This discussion highlights the necessity to explore and identify the factors and underlying dimensions and variables that could contribute to building an effective strategy to enhance consumers' patronage to retail shops. 


\section{An overview of store patronage variables}

Following the discussion above, by using a combination of citations, publication dates and consistent findings from independent studies, the most profound independent variables were summarised to be the following: product quality, service, selection, store atmosphere, price, age, income, sex, selection and store attitude. Table 5 illustrates the findings in greater depth.

\section{Insert 'Table 5: Scholars' Description of the independent variables that affect store patronage’ here}

An objective-based model of store patronage is required to fully adapt the application of the theory of the variables that are highlighted in Table 5 into real-world, actionable processes. After a variety of objective models related to store patronage are identified (Babin and Babin, 2001; Baker et al., 2002; Grewal et al., 2001; Gupta, Su, and Walter, 2004; Hardesty and Suter, 2003; Resnick and Montania, 2003), the question with respect to which one needs to be used becomes apparent.

Due to Baker et al. (2002)'s revision of fifty-nine previous works, and the subsequent acceptance of their model throughout the academic community, their model is 
the one that shall be used to demonstrate the connection between the independent variables, as established in Tables 4 and 5 , and the store patronage of a consumer.

The endeavour of Baker et al. (2002) to show the various stages that the consumers go through on their path of deciding how intensely they will patronise a particular store. This is done via the three stages over which the store has various levels of control.

1. 'Store environment' - The overall 'feel' that the store offers to its consumers is referred to as the 'store environment.' This is demonstrated via social factors (the relationship that store employees have with the consumers), design factors (how the store's architecture and layout make a consumer feel) and ambient factors (the atmosphere of the store, which can be influenced by music and the number of consumers present in the store at any given time) (Baker et al., 2002).

2. 'Store choice criteria' - This encapsulates the perception that the consumer develops from the three factors that have been identified previously. This can be identified using the following five criteria: interpersonal service quality perceptions, merchandise quality perceptions, monetary price perceptions, time/effort cost perceptions and psychic cost perceptions. It is important to note that one of the most important criteria is 'merchandise value perceptions,' which 
encompasses the consumer's view of the gain in value that they can obtain by purchasing a particular product and whether it would justify the cost that they would have to bear while purchasing the product. A purchase will be made only when the value gain is sufficient (Baker et al., 2002).

3. Finally, it is the consumer who will decide how intense their store patronage is, e.g. no purchase, one-off purchase or return visit (Baker et al., 2002).

It is important to note that although a store has command over the 'store environment,' the consumers have command over 'store choice criteria,' e.g. the store can choose its employees based on the employees' perceived closeness with consumers in terms of education, gender and ethnicity. However, if the consumers do not perceive the employees as being a part of their social group, they might perceive them negatively. This connection is very important, as it is an overriding factor that influences store patronage (Baker et al., 2002).

As Nilsson et al. (2015) have suggested, the characteristics of the consumers who patronise certain stores form the key information that the retailers need to take into consideration to change the store attributes and cater to the needs of the consumers as well as that of the potential new consumers. The identification of what store patronage is and how it can be achieved is noteworthy only when the application of store patronage 
has some value in the real world. The latter part of this segment is dedicated to the encapsulation of the real-world value of store patronage. Table 6 highlights the connection that store patronage can have with a store's profit, thereby guaranteeing its practical implementations.

Insert 'Table 6: Correlation of the number of shopping trips with the percentage of spending at first- and second-visited stores [Adapted from Tates (1960)]' here

\section{A proposition of measurements for analyses}

\section{Store image}

Store image has attracted a wide area of research from scholars - from the simple beginnings of Thompson (1967), who conducted a study on the perceived dimensions that affect a consumer's perception on store image, that have grown exponentially to include thirty-two elements currently (Table 2). Although there is little synergy among scholars with regard to what those elements truly are (Lindquist, 1974), some categories of elements are accepted more than others (Table 1). In this paper, research was fashioned upon the previous works of all scholars that have been listed in Table 1 and the outcomes have been defined as a list of elements that have been confirmed to attribute to store 
image with the additional step of placing those elements into a hierarchical order based on the recognition of the factors that affect a consumer more.

Insert 'Table 7: Elements that have been confirmed to have an impact on store image' here

Table 7 was created from the works of the scholars' works that have been highlighted in Table 2 (Benardens, 1963; Doyle and Fenwick,1974; Ghosh, 1994; Grah and Tominc, 2015; Lindquist, 1974; Thang and Tan, 2003; Verma, 2012). Although a number of these studies are dated, they form the building blocks on which store image is built. However, from the analysis of this paper, it can be assumed that, perhaps, some of those elements that influenced a store's image and were previously considered important are of lesser importance now. For example, Lindquist (1974) posited that nine factors influence the store image. However, in this analysis, only three of those have been confirmed within this study (convenience, physical facilities and selection) as compared with the study conducted by Lin and Tominc (2014), which posited nine different elements, seven of which have been confirmed (the exceptions being store facilities and customer service). 
The pattern emerging from the previous studies does not conform to the one that has been found in this paper (Benardens, 1963; Doyle and Fenwick, 1974; Ghosh, 1994; Grah and Tominc, 2015; Lindquist, 1974; Thang and Tan, 2003; Verma, 2012), implying that, with time, consumers have changed their perceptions of what is important in a store, and, therefore, some elements that were earlier perceived to be highly important, such as trading stamps in a promotion (Lindquist, 1974), are no longer considered to be relevant. Although some elements of a store's image have been confirmed in this study and the aforementioned studies, namely styling/fashion, convenience, phone orders, sales clerk service, sales promotion, location, social class appeal, quality, store layout, architecture, delivery, ease of return, guarantee, pricing, reputation and selection, it must be noted that new identifiers of store image have also emerged, such as access to self-service and availability of credit (Grah and Tominc, 2015; Verma, 2012). Another approach to the store image can also seen in the study conducted by Reimers (2014), who found that 25 of the test attributes serve as 'convenience' attributes of department stores. This kind of approach explores whether a specific element of store image factor could also be helpful in providing useful dimensions for the retailers.

In the context of this changing environment, one must perceive the time during which a study has been conducted in relation to its validity, as researchers of store image 
could hold papers by Ghosh (1994), Lin and Tominc (2014), Thand and Tan (2003) and Verma (2012) in higher regard in comparison with papers that are more dated and popular.

\section{Store patronage}

While store image is based on tangible and intangible elements, the perception of store patronage is developed in the minds of the consumers in a less rational manner (Böhler, 2015), resulting in scholars’ attempts to define store patronage by reviewing the degree of store patronage against demographic or situational factors that influence the consumers. This has been listed in Table 4. However, there is little consensus among scholars on the factors that affect store patronage, leaving the scope for the analysis of a wide range of factors. The elements that have been accepted by a substantial number of scholars were further researched in this paper.

Baker et al. (2002), Grewal (2003), Finn and Louviere (1996) and Gehrt and Yan (2004) outlined the elements of store patronage, as shown in Table 4. Although none of them revealed the entirety of store patronage, each one contributed specific elements, building on the works that preceded their own. This modification would not have been possible without the works of Shim and Drake (1990), Woodside and Trappey (1992) and 
Darley and Lim (1993) who incorporated new elements of store patronage into the field of research.

Currently, some more discussions focus on the impact of the digitalised mode of showcasing products on the emotional perceptions of consumers towards retail shops. Sachdeva and Goel (2015) emphasised the importance of the emotional and behavioural engagement of the customers, which implies that retail stores should communicate more with their customers using one-to-one interactions physically before establishing communication through social media, and therefore, physical retail stores should strategically surpass in emotional appeal and interaction with their existing as well as potential customers.

Danziger (2006) suggested that it will be critical to observe how well retailers take into account the emotions, psychology and feelings of the shoppers in the future, that is, ten years later. Sachdeva and Goel (2015) concluded that utilitarian or hedonic values influence customers to enter a store. However, emotions make them stay there and shop. The discussion implies that customer experience, which relates with various elements of store attributes, including products, people, places and the environment, contribute in differing degrees to the overall experience of consumption (Sachdeva and Goel, 2015). 


\section{The impact of store image on consumer patronage behaviour}

The influence of store image on the behaviour of consumers has been broadly acknowledged. It plays a key role in positioning strategy, in which store image is reflected in relation to the type of the retailer and competitors to generate consumers' reactions that are preferable (Berman and Evans, 2013). Communicating a clear and consistent image to the customers is essential to establish a distinguishing image in the minds of the customers. This image is often the source of an effective competitive advantage, as other functional attributes could be limited in terms of differentiating the image of the brand from that of other retailers (Burt and Carralero-Encinas, 2000). Doyle and Fenwick (1974) stated that store image has a critical impact on a store's appeal while reaching out to their customers and, over time, the store image affects customers' patronage behaviour (Mazursky and Jacoby, 1986), which can ensure customer loyalty (Kunkel and Berry, 1968). Store image is the element that influences a customer to choose to frequent a particular shop. Therefore, each retailer's key decision dimensions have to be clearly acknowledged when they attempt to attract customers (Finn and Louviere, 1996). Moreover, retailers should manipulate the consumers' total 
perception of the store's image to encourage consumers' patronage behaviours (Oh et al., 2008).

An understanding of what comprises the store image, how shoppers perceive it and how it influences consumers' patronage behaviour is crucial for developing a successful retail operation. As we have seen, several studies have examined the factors that influence consumers' patronage behaviour in retail shops, and it is claimed that store patronage results from a favourable store image that is developed from a combination of different attributes (Donovan and Rossiter, 1982; Finn and Louviere, 1996; Osman, 1993; Sirgy et al., 2000; Thang and Tan, 2003). It is the stage in which researchers must review the outlines of these academic discussion outcomes and translate them into some practical frameworks that can be adopted by the marketers of retail shops as a holistic approach that can be utilised when building effective marketing strategies.

In the context of academic research, new elements have been added to the store image’s analytical map, such as a retail store’s environmental cues (Baker et al., 2002; Carpenter and Moore, 2006). Verma (2012) investigated the impact of a store's attributes across apparel retail stores and store formats. Researchers have already indicated that some other key drivers, which are relatively similar to store image 
attributes, determine the store choice of customers (Tang et al., 2001), which, in turn, influences patronage behaviour. In this sense, it is required for us to review and sift through the essential dimensions of store image so that marketers and retailers can implement them while drafting their strategies, as there are different dimensions with a variety of measurements that are proposed in the academia, which are deepening and widening the analytical scope and which could contribute to the practice of this field of study.

\section{Conclusion}

\section{Overall findings and implication}

This study has critically reviewed the literature that explores the relationships between store image and store patronage behaviour, which could provide useful insights and implications for marketers and retailers. The articles that have been published in the relevant academic journals during the last fifty years were examined and discussed. In particular, this paper sought to present a critical review of the relations between these two key concepts and practical measurements, which could contribute to the development of research perspectives. 
It has been found that within the following eight identified dimensions of store image: merchandise, service, convenience, promotion, clientele, physical facilities, atmosphere and institutions, there are corresponding sub-sections that must be recognised, e.g. merchandise involves quality, assortment, price, fashion and guarantee. These dimensions have been analysed and discussed in the context of their impact on store patronage. However, due to the lack of clarity with respect to predictors of store patronage, there has been some confusion in academic discussions till this date.

As discussed by Pan and Zinkhan (2006), store patronage can be linked to two parameters, namely, the alignment of the customers' store image with that of the managers' store image. This implies that the areas that managers perceive to be important are not necessarily aligned with the areas that the consumers consider to be important. Therefore, it is suggested that store patronage should be investigated in line with the two parameters in the first place - the alignment of the customer's store image with that of the manager's store image and past purchase experiences. This point has not been discussed in an organised manner in previous studies, as the previous studies have neither sufficiently addressed nor explored this analytical approach.

This study also shows that most studies used two key terms, namely, store image and store patronage separately, and that the holistic analytical platform has not been 
proposed so far. Therefore, the proposition of the analytical tool that focusses on the two parameters, namely, store image alignment of customers and managers and past purchase experiences of customers, should be considered to be an useful tool by both researchers and managers. This finding and suggestion from this study can shed light on the academic discussions in the literature by providing a useful paradigm to researchers for enhancing critical investigations, which can lead to the development of academic and practical implications for both researchers and practitioners.

\section{Limitations}

Retail service needs to create a reinvented discussion platform based on the factors of store image and store patronage. As indicated in this study, consumers may use store image that is embedded in the store environment as a trigger for their patronage behaviour. Although the outcome of this study provides practical dimensions for the marketers to investigate while formulating marketing strategies to attract consumers, this study has remained a literature review that provides a conceptual framework for further examination with real data. Some empirical analyses are needed to present more robust framework to build a marketing strategy for the retailers to enable them to enhance the impact of this study. 


\section{Recommendation}

This study presents holistic reappraisals of the initial literature with regard to the holistic development, implications and impact of store image on store patronage. Based on this outcome, a more robust discussion paradigm is required to develop the perspectives that can bridge the gap between store image and store patronage. This study could enhance open discussions, inviting researchers and practitioners to explore and identify some more unique factors to which attention has not been directed so far. It is also suggested that future researchers should discuss and adapt the store image based on the customers' perception to build marketing strategies and increase patronage, especially in the current globalised era, with a variety of different local and cultural conditions.

\section{References}

Anna, Z., hyphen, Fraser and Campbell, F. (2002), “Store patronage prediction for foreign-owned supermarkets”, International Journal of Retail \& Distribution Management, Vol.30 No.6, pp. 282-299. 
Arnold, S. J., Oum, T. H. and Tigert, D. J. (1983), “Determinant attributes in retail patronage: Seasonal, temporal, regional, and international comparisons”, Journal of Marketing Research, Vol.20 No.2, pp.149-157.

Arons, L. (1961), “Does Television Viewing Influence Store Image and Shopping Frequency-A Research Study in The Mid-West”, Journal of Retailing, Vol. 37 No. 3, pp.1-13.

Babin, B. J. and Babin, L. (2001), "Seeking something different? A model of schema typicality, consumer affect, purchase intentions and perceived shopping value”, Journal of Business Research, Vol. 54 No. 2, 89-96.

Babin, B, J., Hardesty, D., Suter, T. A. (2003), “Color and Shopping Intentions: The Intervening Effect of Price Fairness and Perceived Affect”, Journal of Business Research, Vol.56 No. 7, pp. 541-551. 
Bagdare, S. (2015), “Emotional Determinants of Retail Customer Experience”, International Journal of Marketing \& Business Communication,Vol. 4 No.2, pp.9-16.

Baker, J., Baker, J., Grewal, D., Voss, G. B. and Parasuraman, A. (2002), “The influence of multiple store environment cues on perceived merchandise value and patronage intentions”, Journal of Marketing, Vol. 66 No. 2, pp.120-141.

Baumeister, R. F. (2013), Writing a literature review. In M. J. Prinstein \& M. D. Patterson (Eds.), The portable mentor: Expert guide to a successful career in psychology (pp. 119-132; 2nd ed.). New York: Springer Science.

Belwal, R. and Belwal, S., (2017), "Factors affecting store image and the choice of hypermarkets in Oman”, International Journal of Retail \& Distribution Management, Vol.45 No.6, pp.587-607.

Berman, B. and Evans, J. R. (2013), Retail Management: A Strategic Approach, 12th edition. Harlow: Pearson. 
Bhat, I. H. and Singh, S., (2017), "Exploring the relationship between store image and store loyalty of an organized grocery retail”, CLEAR International Journal of Research in Commerce \& Management, Vol.8 No.10, pp.44-46.

Biswas, A. and Blair, E. A. (1991), “Contextual effects of reference prices in retail advertisements”, Journal of Marketing, Vol. 55 No. 3, pp.1-12.

Birtwistle, G., Clarke, I. and Freathy, P. (1999), "Store image in the UK fashion sector: consumer versus retailer perceptions”, The international Review of Retail Distribution and Consumer Research, Vol. 9, No. 1, pp. 1-16.

Böhler, C. (2015), “A Thin Line between the Rationalization of Consumer Choices and Overburdening Market Participants. Are the Courts Able to Keep the Balance?”, European Food \& Feed Law Review, Vol.10 No.1, pp.34-39.

Boulding, K. E. (1956), “General systems Theory- The skeleton of science”, Management Science, Vol. 2 No.3, pp.197-208. 
Boulding, K. (1950), “Collective Bargaining and Fiscal Policy”, The American Economic Review, Vol. 40 No.2, pp.306-320.

Bucklin, L. P. (1963), "Retail strategy and the classification of consumer goods", Journal of Marketing, Vol. 27 No. 1, pp.50-55.

Burt, S. and Carralero-Encinas, J. (2000), “The role of store image in retail internationalisation”, International Marketing Review, Vol. 17 No.4/5, pp.433-453.

Carpenter, J. M. (2008), “Demographics and patronage motives of supercenter shoppers in the United States”, International Journal of Retail \& Distribution Management, Vol. 36 No.1, pp.5-16. 
Carpenter, J. M. and Moore, M. (2006), “Consumer demographics, store attributes, and retail format choice in the US grocery market”, International Journal of Retail \& Distribution Management, 34 (6), pp.434-452.

Chrysochou, P. (2010), “Food health branding: The role of marketing mix elements and public discourse in conveying a healthy brand image”, Journal of Marketing Communications, Vol. 16 No. 1-2, pp.69-85.

Clement, J., Aastrup, J. and Charlotte Forsberg, S. (2015), “Decisive visual saliency and consumers' in-store decisions”, Journal of Retailing and Consumer Services, Vol. 22, pp. 187-194.

Cooper, H. M. (2003), Editorial. Psychological Bulletin, 129, pp.3-9.

Cox, K. (1964), “The responsiveness of food sales to shelf space changes in supermarkets”, Journal of Marketing Research, Vol. 1 No. 2, pp.63-67. 
Darian, J. C., Tucci, L. A. and Wiman, A. R. (2001), “Perceived salesperson service attributes and retail patronage intentions”, International Journal of Retail \& Distribution Management, Vol. 29 No. 5, pp.205-213.

Danziger, P. (2006), Shopping: Why We Love it and How Retailers can Create the Ultimate Customer Experience, Kaplan Publications, pp. 15-21.

Diallo, M. F. and Cliquet, G. (2016), "Store image perceptions and customer knowledge cues in emerging markets”, International Journal of Retail \& Distribution Management, Vol. 44 No.12, pp.1182-1205.

Delener, N. (2011), “Determinants of Retail Patronage: A Cross Cultural Experiment”, Proceedings of the Northeast Business \& Economics Association, pp.121-124.

Don, J., Durand, R. and Dreves, R. (1976), "Use of a multi-attribute attitude model in a store image study”, Journal of Retailing, Vol. 52 No.1, pp.23-32. 
Donovan, R. J. and Rossiter, J. R. (1982), “Store Atmosphere: An Environmental Psychology Approach”, Journal of Retailing, Vol. 58 No.1, pp.34-57.

Doyle, P. and Fenwick, I. (1974), “How store image affects shopping habits in grocery chains”, Journal of Retailing, Vol. 50 No. 4, pp. 39-52.

Drichoutis, A. C., Lazaridis, P. and Nayga, R. M. (2007), “An assessment of product class involvement in food- purchasing behaviour”, European Journal of Marketing, Vol. 41 No. 7/8, pp.888-914.

Engel, B. M. and Blackwell, R. D. (1982), Consumer Behaviour, 4th edition, Dryden Press, Orlando. 
Erdem, O. and Oumlil, A. B. (1999), "Consumer values and the importance of store attributes”, International Journal of Retail \& Distribution Management, Vol. 27 No. 4, pp. 137-144.

Finn, A. and Louviere, J. J. (1996), “Shopping center image, consideration, and choice: Anchor store contribution”, Journal of Business Research, Vol. 35 No. 3, pp. 241-251.

Gehrt, K. C. and Yan R-N. (2004). "Situational, consumer, and retailer factors affecting Internet, catalog, and store shopping”, International Journal of Retail \& Distribution Management, Vol. 32 No. 1, pp. 5-18.

Gil-Saura, I., Molina, M. E. R. and Berenguer-Contri, G. (2016), "Store equity and behavioral intentions: the moderating role of the retailer's technology”, Journal of Product \& Brand Management, Vol. 25 No. 7, pp.642-650.

Goodman, S. and Remaud, H. (2015), “Store choice: How understanding consumer choice of 'where' to shop may assist the small retailer", Journal of Retailing and Consumer Services, Vol.23, pp.118-124. 
Grah, M. and Tominc, P. (2015), "Relationships among Store Image and Store Loyalty in Slovenia”, Povezave med podobo prodajalne in zvestobe do prodajalne v Sloveniji, Vol. 61 No. 6, pp. 28-37.

Groß, M. (2014) “Mobile shopping: a classification framework and literature review”, International Journal of Retail \& Distribution Management, International Journal of Retail \& Distribution Management, Vol. 43 No. 3, pp.221-241.

Gupta, A., Su, B., and Walter, Z. (2004), “An empirical study of consumer switching from traditional to electronic channels: A purchase-decision process perspective”, International Journal of Electronic Commerce, Vol. 8 No. 3, pp. 131-161.

Houston, M. J. and Nevin, J. R. (1981), “Retail Shopping Area Image: Structure and Congruency between Downtown Areas and Shopping Centers”, Advances in Consumer Research, Vol. 8 No. 1, pp. 677-681. 
Hsu, M. K., Yinghua, H. and Swanson, S. (2010), “Grocery store image, travel distance, satisfaction and behavioral intentions”, International Journal of Retail \& Distribution Management, Vol. 38 No.2, pp.115-132.

Hu, H. and Jasper, C. R. (2006), "Social cues in the store environment and their impact on store image”, International Journal of Retail \& Distribution Management, Vol. 34 No. 1, pp. 25-48.

Jean, C. D., Louis, A. T. and Alan, R. W. (2001), "Perceived salesperson service attributes and retail patronage intentions”, International Journal of Retail \& Distribution Management, Vol. 29 No. 5, 205-213.

Jha, M. and Arora, S. (2012), “Impact of Various Situational Factors on Store Image, Satisfaction and Loyalty of Customers Study on Pantaloon Store”, Journal of Contemporary Research in Management, Vol. 7 No.2, pp.21-30.

Jolson, M. A. and Spath, W. F. (1973), “Understanding and Fulfilling Shoppers' Requirements”, Journal of Retailing, Vol. 49 No. 2, pp. 38-46. 
Kaul, S., Sahay, A. and Koshy, A. (2010), “Impact of initial-trust-image on shopper trust and patronage intentions”, International Journal of Retail \& Distribution Management, Vol. 38 No. 4, pp. 275-296.

Kelly, J. P. and Smith, S. M. (1983), “Determinants of Retail Patronage: An Examination of Alternative Models”, Advances in Consumer Research, Vol. 10 No.1, pp. 345-350.

Korgaonkar, P. (1985), “A structural equations approach toward examination of store attitude and store patronage behaviour”, Journal of Retailing, Vol. 61 No. 2, pp. 39-60.

Kunkel, J. H. and Berry, L. L. (1968), “A Behavioral Conception of Retail Image”, Journal of Marketing, Vol. 32 No.4, pp.21-27. 
Levy, Y. and Ellis, T.J. (2006), “A systems approach to conduct an effective literature review in support of information systems research”, Informing Science Journal, Vol. 9, pp. 181-212.

Lindquist, J. D., Vida, I., Plank, R. E. and Fairhurst, A. (2001), “The modified CETSCALE: Validity tests in the Czech Republic, Hungary, and Poland”, International Business Review, Vol. 10 No. 5, pp. 505-516.

Lindquist, J. (1974), “Meaning of Image: A survey of empirical and hypothetical evidence”, Journal of Retailing, Vol. 50 No. 4, pp. 29-37.

Martineau, P. (1958), “The personality of the retail store”, Harvard Business Review, Vol. 36, pp. 47-55. 
Maruyama, M. and Wu, L. (2014), “Multiple store patronage: The effects of store characteristics”, Journal of Retailing \& Consumer Services, Vol. 21 No. 4, pp. 601-609.

Mazursky, D. and Jacoby, J. (1986). “Exploring the Development of Store Images”, Journal of Retailing, Vol. 62 No.2, pp.145-165.

Nilsson, E., Marell, A., Nordvall, A. C. and Gärling, T. (2015), "Who shops groceries where and how? - the relationship between choice of store format and type of grocery shopping”, International Review of Retail, Distribution and Consumer Research, Vol. 25 No. 1, pp.1-19.

Ogle, J. P., Hyllegard, K. H. and Dunbar, B. H. (2004), “Predicting Patronage Behaviors in a Sustainable Retail Environment: Adding Retail Characteristics and Consumer Lifestyle Orientation to the Belief-Attitude-Behavior Intention Model”, Environment \& Behavior, Vol. 36 No. 5, pp. 717-741. 
Oh, J., Fiorito, S. S., Cho, H. and Hofacker, C. F. (2008), "Effects of design factors on store image and expectation of merchandise quality in web-based stores”, Journal of Retailing and Consumer Services, Vol 15. No.4, pp.237-249.

Osman, M. Z. (1993), “A conceptual model of retail image influences on loyalty patronage”, The International Review of Retail, Distribution, and Consumer Research, Vol. 3, No. 2, pp. 133-148.

Pan, Y. and Zinkhan, G. M. (2006a), “Determinants of retail patronage: A meta-analytical perspective”, Journal of Retailing, Vol. 82 No. 3, pp. 229-243.

Pan, Y. and Zinkhan, G. M. (2006b), "Exploring the impact of online privacy disclosures on consumer trust”, Journal of Retailing, Vol. 82 No.4, pp. 331-338.

Rao, A. R. and Monroe, K. B. (1988), “The moderating effect of prior knowledge on cue utilization in product evaluations”, Journal of Consumer Research, Vol. 15 No. 2, pp. 253-264. 
Reimers, V. (2014), “A consumer definition of store convenience (finally)”, International Journal of Retail \& Distribution Management, Vol. 42 No. 4, pp.

315-333.

Reimers, V. and Clulow, V. (2009), "Retail centres: it is time to make them convenient”, International Journal of Retail \& Distribution Management, Vol. 37 No.7, pp. 541-562.

Resnick, M. L. and Montania, R. (2003), “Perceptions of customer service, information privacy, and product quality from Semiotic design features in an online web store”, International Journal of Human-Computer Interaction, Vol. 16 No.2, pp.211-234.

Sachdeva, I. and Goel, S. (2015), “Retail store environment and customer experience: a paradigm”, Journal of Fashion Marketing \& Management, Vol.19 No.3, pp.290-298. 
Sirgy, M. J., Grewal, D. and Mangleburg, T. (2000), "Retail Environment,

Self-Congruity, and Retail Patronage. An Integrative Model and a Research Agenda”, Journal of Business Research, Vol. 49, pp. 127-138.

Steenkamp, Em, J.-B. and Wedel, M. (1991), “Segmenting retail markets on store image using a consumer-based methodology”, Journal of Retailing, Vol. 67 No. 3, pp.300-320.

Stephenson, P. R., (1969), “Identifying Determinants of Retail Patronage”, Journal of Marketing, Vol. 33 No. 3, pp. 57-61.

Sullivan, P. and Savitt, R. (1997), “Store patronage and lifestyle factors: Implications for rural grocery retailers”, International Journal of Retail \& Distribution Management, Vol. 25 No. 11, pp. 351-364. 
Tang, C. S., Bell, D. R. and Ho, T.-H. (2001), “Store Choice and Shopping Behavior:

How Price Format Works”, California Management Review, Vol. 43 No.2, pp.56-74.

Tate, R. S. (1961), “The supermarket battle for store loyalty”, Journal of Marketing, Vol. 25 No. 6, pp. 8-13.

Thang, D. C. L. and Tan, B. L. B. (2003), “Linking consumer perception to preference of retail stores: an empirical assessment of the multi-attributes of store image”, Journal of Retailing and Consumer Services, Vol.10 No.4, pp.193-200.

Thelen, E. M. and Woodside, A. G. (1997), "What evokes the brand or store? Consumer research on accessibility theory applied to modeling primary choice”, International Journal of Research in Marketing, Vol. 14 No. 2, pp. 125-145. 
Theodoridis, P. K. and Chatzipanagiotou, K. C. (2009), "Store image attributes and customer satisfaction across different customer profiles within the supermarket sector in Greece”, European Journal of Marketing, Vol. 43 No. 5-6, pp. 708-734.

Thompson, B. (1976), “An Analysis of Supermarket Shopping Habits in Worcester, Massachusetts”, Journal of Retailing, Vol. 43 No. 3, pp. 17-29.

Verma, H. (2012), “Measuring Store Image: An Empirical Study in Some Selected Apparel Retail Stores”, Amity Management Review, Vol. 2 No.2, pp.2-18.

Walters, R. G. and Rinne, H. J. (1986), “An empirical-investigation into the impact of price promotions on retail store performance”, Journal of Retailing, Vol. 62 No.3, pp.237-266.

Webster, J. and Watson, R.T. (2002), “Analyzing the past to prepare for the future: writing a literature review”, MIS Quarterly, Vol. 26 No. 2, pp. xiii-xxiii. 
Yavas, U. and Babakus, E. (2009), "Retail store loyalty: a comparison of two customer segments”, International Journal of Retail \& Distribution Management, Vol. 37 No. 6, pp. 477-492. 